Original Article

Received/Accepted

Dates

19.08.2021/15.09.2021

DOI

10.52096/jsrbs.6.1.7.13.26
Journal of Social Research and Behavioral Sciences

Sosyal Araştırmalar ve Davranış Bilimleri Dergisi

ISSN:2149-178X

Volume: 7 Issue: 13 Year: 2021

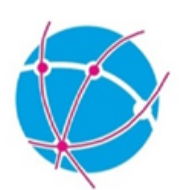

\title{
Participation in Governance: Challenges and Achievements of Representative Democracy in
}

Albania

\section{ALI ZAIMI ${ }^{1}$}

\begin{abstract}
The system of representative democracy has its origins in England. Participation in governance is an important element of representative democracy because the people exercise their power through representatives. This paper aims to analyze the challenges and achievement of representative democracy in Albania after the fall of communism regime. Since 1990, Albania entered into a period of transition where participation in governance was seen as positive element to approach western values.

This paper seeks to address the following question: Does the development of representative democracy help participation in governance? Whom does the power belong to, and how should this power be exercised? Can the people, participate in governance, and control the representatives, if they do not properly represent it? How can power be returned to the people?

Main methodology used in this paper is doctrinal research.

The paper is structured in three sections. After the introduction (section 1), the paper discusses theoretical framework of representative governance and the importance of participation in governance. The third section analyzes the challenges of representative democracy in the context of Albania.
\end{abstract}

Keywords: Democracy; Governance; Participation;

\footnotetext{
${ }^{1}$ University College Beder, Department of Islamic Sciences, azaimi@ beder.edu.al
} 


\section{Introduction}

Participation in governance is one of the most important elements which express the level of democracy and the rule of law, and effects the foundations of a country's state and development. Participation in governance means, to participate in country public life, and to decide on issues of concern to the community, thus being governed not only by elected representatives, but sometimes also directly by citizens. Cooperation between the state and the citizens is needed, and the sovereignty of the people must be respected, in the service of participation in governance.

After some faults of direct democracy, representative democracy was developed while preserving some important elements of direct democracy such as referendums, plebiscites, etc., which expressed and helped expand the citizen participation in governance.

The representative system, in the contemporary sense, was firstly introduced in England (14th Century) with the constitution of the English parliament as a representative body, consisting of two chambers. After the democratic revolutions, this system, combined with the forms of direct democracy, was emerged in the US, France, and many other European countries. (Saliu 2004, 297) Saliu $(2004,296)$ defines the representative system "as an indirect form of sovereignty. This system is based on the theory of the sovereignty of the nation, according to which, the nation, as a collective body or people or individuals, exercises sovereignty through its elected representatives."

In addition to participation, political culture and the rights and obligations of citizens are important to keep power within the proper limits. Public opinion, free elections, and the media are other elements that can affect participation in governance.

Is there a democracy of criticism today or just a democracy of polls?! Polls can have a positive or negative effect on voters by influencing their willpower.

Forms of direct democracy, which are also part of representative democracy, are referendums, plebiscites, etc. There are achievements that have been reached, but even today there are still problems in Albania, which in some cases they have given partial results regarding the 
participation in government, but in other cases they have not brought the proper effects, or have not been allowed at all,

2. The participation in governance of the people within the framework of power, or representative democracy

Representative democracy has got many positive elements, but there are also some elements that can be discussed. Tinder argues that questions that often have been raised for discussion are as follow: Does the development of representative democracy help participation in government? Who does the power belong to, and how should it be exercised? If power belongs to the people, should people exercise it themselves or through their representatives? (Tinder 1993, 98) Rousseau, well know philosopher, criticizes representative democracy arguing that if the sovereign, who in this case is the people, transferred his power and sovereignty to his representatives in state institutions, he could no longer be sovereign, and he cannot have the rights and freedoms that belonged to him. Taking the example of UK, Rousseau emphasized that "sovereignty [...] cannot be represented. The English people think that they are free; but they are wrong: people are free until they elect the members of the parliament. The moment the parliament is elected, slavery is restored and the people have no rights." (quoted to Tinder 1993, 98)

Lincoln has noted that the government belongs to the people and the well-known statement "government of the people, from the people, for the people" must be respected. (Sartori 1998, 23) But in the system of representative democracy, the people have transferred their sovereignty to their representative. The latter to represent the people in government affairs. If we had a government of the people, from the people, and of "over the people" as Sartori (1998, 22-23) noted, how would be seen because the participation was just only for appearance and not for the substance. In this context, we would have a government of power, from the power and for the power. (Sartori 1998, 22) Furthermore, it is well known that people delegates sovereignty to representatives but in turn, this delegated sovereignty is "over the people". But is it people's power 
over the people, as Sartori expressed it? (Sartori 1998, 22) So, people elect, they delegate power, and then this power is delegated over the people. Can the people control the power that it has been delegated to their representatives, and, can the people participate in government if the representatives do not properly represent it? It should be said that for the representative democracy "the relationship between the electors and the representatives elected by them is of a particular importance." (Saliu 2004, 297) As Mayer et al. emphasize "the constitutional format must be established as legitimate for the efficient resolution of fundamental issues and disagreements, such as the extension of effective participation in system policy to an ever wider spread segment of the population.” $(2003,13-14)$.

Today, in modern times, we still encounter problems with democracy until it is demanded that: "Power shall be returned to people" (Dulhamel 2004, 40), because the ruling power has taken power from people and citizens. But, how can one start acting, so citizens could achieve what they need? As Dulhamel puts: "Reclaiming the word and recreating collegiality within government 'strict sensu' is a primary importance constitutional objective" $(2004,43)$. So, "We have to start by reclaiming the word ... and reclaiming it from the top of the state ... It is necessary that word must be organized in between the state and society", even if the word is not given." (Dulhamel 2004, 42-43)

But, how can be understand the government participation and its limitations of power? Can the participation in governance be achieved? If the answer is positive, when can we say that this participation has actually been achieved, and is not a merely fictitious or fake participation. According to Sartori, governance participation does not mean individual freedom since my freedom does not stem from power. On the contrary, 'control and restriction of power' can be defined as an attempt to solve the problem of oppression of man by man, by demanding for everyone the individual freedom' (Sartori 1998, 117) Participation in government means not only participating in state affairs, but also bringing solutions to issues concerning community. Thus, citizens participate in the decision-making process not only through their representatives but also through participating directly. The question 'who should rule', Glen Tinder $(1993,94)$ answers: "Anyone" and "no one". 
But, does the state undermines the rights, freedoms and citizens participation in governance? According to John Locke $(1960,348)$, “people are by their free nature, equal and independent”. In other words, people have their will and rights that cannot be violated. It should be noted that representative democracy "does not close the gap between the government and people, and as realistic as it is, it does not even attempt to do so.” (Tinder 1993, 101)

According to Rousseau "giving up from freedom means to give up being a human being". (Rousseau 1950, 9 and 29) Thus, everyone has to express his/her ideas. Jurgen Habermas, a German philosopher notes that a "reasoned will" should be formed, where there is public space for discussion for request and decision of the sovereignty without leaving justification the state to intervene and restrict the rights. (quoted in Dulhamel 2004, 43)

What is the power and how far has it come!? According to Oliver Dulhamel (2004, 43), "a minister, who left the position after a change was privately confessed that he had never seen a community where people disregard each other to that point." The state government must involve its citizens in decision-making process in the public interest. There must be cooperation between the state and citizens to resolve problems, to further develop democracy and participation and in the same time to respect constitutionality, legality and sovereignty of the people.

Aside from other things, also the political culture matters for participation and democracy. Political culture includes "attitudes towards authority; beliefs or conceptions about truth; a logical or pragmatic method for decision making." (Mayer et al. 2003, 14) It should be said that: "values of a political nature are very important and, therefore, cannot be easily eliminated: these values define the framework of social life - the foundation of our existence - and specify the essential conditions of political and social cooperation. [...] These values also include the values of justice [...] as well as the social foundations of citizens' respect for themselves." (Rawls 2007, 315)

In order to have a consolidated democracy which forms the basis for the individual, society and state institutions, citizens must have their rights and obligations; there must be not only formal procedural aspects but also substantive and real. So, there should be "a normative softening of political power through essential rights." (Habermas 2005, 125) According to Hegel $(1952,71)$, 
the individual "is not properly respected ... if treated as ... a human being who needs to be restrained or transformed." Also, some elements of a representative democracy of the EU have to be fulfilled where the expansion of the political rights of Europeans aims reinforcing their participation in European decision-making processes and their ability to shape the orientations of the Union. This political development, which puts some of the Union's political orientations at the discretion of the citizens, marks a progress in the field of democracy. (Soin 2008, 197)

Another important element that may or may not affect participation in governance and representative democracy is public opinion. According to political analyst Dicey, "the opinion of the citizens is the real foundation of any government." (Dicey 1905) "Free elections with imposed (not free) opinions have no values. A sovereign society who has nothing to share, without its own opinions, is an empty sovereign society, a disgusting king”. (Sartori 1998, 45) "Today, politics is exercised through media and its coercion. It exploits and is influenced by common surveys." (Dulhamel 2004, 40) But, often media is referred as the fourth power and has its importance in democratic processes. The problem is whether this fourth power is or not part of the sovereignty of the people and whether it protects and serves to these people. Of course, the media facilitates participation in democracy by giving space for free thought and public debate. But political analyst Oliver Dulhamel states that "The predominance of Hertzian and commercial television (public or private) over any other means of communication clearly disrupts public debate ... Today the information has been reduced to its simplest expression ... Political speech is audible ... only if it contains some shocking expression, something unexpected ...” (Dulhamel 2004, 40).

But, to what extent do the above elements serve the public interest, democracy and participation? Do these elements serve the power and the rulers and not the sovereign (citizens)?! It must be stated that, the fourth power is of great importance to democracy because: "TV images reveal personalities, expose lies or mistrusts, ruin wooden language and value authenticity." (Dulhamel 2004, 41).

Oliver Dulhamel asks if there is a democracy of uprisings and surveys today? This element is also an important barometer to measure participation in governance and representative democracy. According to Dulhamel, "governments and citizens communicate through surveys. Many 
barometers show each month the popularity of various ministers and key opposition responsibilities, how they will be voted in legislative or presidential elections, as well as control or lack of control of the government from the opinion. To these ongoing, true and false elections, the population-based questionnaire is added - a representative sample of measures taken or anticipated by the government, current political conflicts and almost every real issue." (Dulhamel $2004,42)$

But how do surveys/polls affect voting? Do they have a positive effect or do they negatively affect the opinion of voters and their will? "On the one hand, the use of surveys in media, and on the other hand, the political use of surveys, forces us to reflect on the political and social consequences of these permanent surveys on the public and above all, on their extremely simplified distribution, so distorted." (Dulhamel 2004, 42) Political surveys are important but they should be used correctly because: "Political surveys, aside from being a commercial tool for the companies that sell them, should be not only a recognition tool for science and political actors, but also a communicating tool between the governments and citizens. They just need to be used correctly." (Dulhamel 2004, 42)

3. Direct democracy instruments facing the challenges of representative democracy in Albania

Indeed, some forms of direct democracy incorporated in representative democracy have been very successful, but today there are still some problems with participation in representative democracies in Europe, in the U.S., and Albania. In representative democracy. "The role of voters is narrowed down to only electing representatives and ends with it. During the term, the elected representative... is not accountable to the electorate for his/her work and they have no right to revoke it before the mandate is over" (Saliu 2004, 258).

Some mechanisms of direct democracy that are part of representative democracy, inter alia, referendum, the people's initiative and plebiscite. It should emphasized that these mechanism "have not solved the crucial problem, removing the ability people (the bearer of sovereignty) from making state decisions." (Saliu 2004, 290) According to Kurteshi, "The referendum, as a form of direct election, is important because through it the people realize, partially, their sovereignty". 
(Saliu 2004, 293) However, the case of Napoleon I and III, Hitler Mussolini demonstrated that the referendum can be misused by the authorities.

Currently, these mechanisms of direct democracy which are part of representative democracy are facing many obstacles and problems. For instance, for a referendum to succeed, certain conditions must be fulfilled. Firstly, the electorate should be able to freely express frely their will. And secondly, the citizens must be informed about the issue in order to take a decision. On the other hand, people's initiative on the issues which concerns community depends on the public authorities whether to succeed further or to be rejected. (Saliu 2004, 293-296)

In Albania, forms of direct democracy have also been adopted and used, where in some cases they have produced the desired results, but in other cases, they have failed to do so. Albanian Constitution was adopted by a referendum in 1998 and was last amended in 2020. Albania is a parliamentary republic (Art 1/1) and the sovereignty belongs to the people. (Art 2/1) According to article $2 / 2$ of the Albanian Constitution, the people exercise sovereignty through their representatives or directly. Based on Article 2/2, firstly, the people exercise their sovereignty through their representatives. Representative democracy is recognized in local government and in central government.

Whereas the second form recognized by Article 2/2 is when people exercise the sovereignty directly. Albanian Constitution in part eleven regulates the referendum. Accordingly, "The people, through 50 thousand citizens, who enjoy the right to vote, have the right to a referendum for the abrogation of a law, as well as to request the President of the Republic to hold a referendum about issues of special importance." (Article 150/1) However, Article 152/2 stipulates that referendum is not possible for the following issues: the territorial integrity of the Republic of Albania, limitations of fundamental human rights and freedoms, budget, taxes, financial obligations of the state, declaration and abrogation of the state of emergency, declaration of war and peace, as well as amnesty. 
The following section provides some examples of referendum based on Constitutional practice. Generally, the Constitutional Court of Albania has considered the referendum as an important tool for the development of participation in government, the exercise of the sovereignty of the people, and the development of the rule of law. But only in a few cases was a referendum allowed, giving the leading role to representative institutions. According to the Constitutional Court, "Instruments of direct democracy are suitable, not as the competing power of representative bodies, but as an instrument that enables and balances the acts of representatives. The provisions of the Constitution allow the exercise of sovereignty of the people through referendums, as long as this is not against the system of the legislative process. It does not enable law making, a function which is exclusively entrusted to lawmakers." 2

In 1995, the Constitutional Court of the Republic of Albania decided: "The rejection of the claims... for the unconstitutional declaration of law no.7866, dated 10.10.1994 "On referendums", its 2nd Article, and the verdict of the People's Assembly no.262, dated 10.10.1994 "On the approval of the Constitution of the Republic of Albania by referendum."

In 1997, in Albania there were objections concerning the way the referendums were conducted. "The Movement of Legality Party demanded the abolition of verdict of the Central Election Commission no.1355, dated 13.07.1997 of the "On the proclamation and successful referendum outcome", by presenting these violations: The voting process was characterized by serious faults both before and during the voting process and particularly in the final counting of votes ..., voters' lists and ballots, - but this was rejected by the Constitutional Court as an unconstitutional claim.

In Albania, claims for referendums in most cases have been rejected. The Constitutional Court of the Republic of Albania unanimously decided that: "the claim for the abolition of Articles 4 and 6 of the Law 8888/2002 "On some additions and amendments to the Law no.7703/1993 "On social security in the Republic of Albania.... is incompatible with the Constitution".

On 29 May 2008, at Central Election Commission (CEC) was submitted a claim from 24 electors to initiate procedures for holding a general referendum on abrogating Articles 5, 7 and 8 of Law

\footnotetext{
${ }^{2}$ Vendimi nr. 31, datë 19.11.2003, Gjykata Kushtetuese e Republikës së Shqipërisë.
} 
no.9904, dated 21.04.2008 "On some amendments to the Law no.8417, dated 21.10.1998 "The Constitution of the Republic of Albania", as amended... - The Constitutional Court of the Republic of Albania declared: "as incompatible with the Constitution, and decide to reject the claim, to abrogate the verdict of the Central Election Commission no.47, dated 05.06.2008.”

Also, the Constitutional Court declared in 2011: as compatible with the Constitution the claim for holding a general referendum on the abrogation of Article 22, paragraph 3, and Article 49 of Law no. 10463, dated 22.09.2011 "On Integrated Management of Waste."

There are still problems everywhere concerning the participation of citizens in representative democracy and, as Henry Bergson stated: "Nothing is finished, everything is in formation, no situation is immutable, and everything's changing." (Bergson 1946)

\section{Conclusions}

Direct democracy has shown some drawbacks, and that's why representative democracy was developed, while retaining some important elements of direct democracy, such as referendums, plebiscites, etc. These elements helped in developing citizen participation in governance, and the further consolidation of representative democracy.

The system of representative democracy has its origins in England. In this system, the people exercise their power through their representatives. There has been criticism of representative democracy. When the sovereign people transferred power to their representatives, they could no longer be sovereign, and could no longer have the rights and freedoms that belonged to them. That's why participation in government means not only being engaged and participating in country public life, but also by controlling the representatives and when necessary applying forms of direct democracy, such as referendum and plebiscite. Other important elements that may affect participation in governance and representative democracy are public opinion, free elections, media, polls, political culture, referendum, etc.

It is true that some forms of direct democracy, incorporated in representative democracy, have been achieved, but in other cases they failed. In most cases in Albania, it is noticed that the requests for the referendum were not accepted, because they have been judged as incompatible with the 
Constitution. However, the Constitutional Court of Albania, in its practice, has considered the referendum as an important tool for the development of participation in government, the exercise of the sovereignty of the people, and the development of the rule of law. But only in a few cases referendum has been allowed, and the most important role has remained to representative institutions.

\section{References:}

Bergson, Henri., (1946), The Creative Mind: An Introduction to Metaphysics, New York, Philosophical Library

Dicey, Albert Venn., (1905), Lectures on the Relation Between Law and Public Opinion in England during the XIX Century, London, MacMillan

Dulhamel, Oliver., (2004), The constitutional right-Democracies, Logos-A, Skopje

Habermas, Jurgen., (2005), The divide west, Asdreni Publishing House, Skopje

Hegel, Friedrich., (1952), Philosophy of Rights, T.M. Knox (tr), Oxford: Clerandon Press

Judgment of 23 February 1995 of Constitutional Court of the Republic of Albania, D-3/1995.

Judgement of 27 August 1997 of Constitutional Court of the Republic of Albania, D-44/1997.

Judgment of 19 November 2003 of Constitutional Court of the Republic of Albania, D-31/2003.

Judgment of 24 July 2009 of Constitutional Court of the Republic of Albania, D-25/2009.

Judgment of 21 January 2011 of Constitutional Court of the Republic of Albania, D- 5/2011. 
Locke, John., (1960), Two Treatises of Government, Peter Laslett (ed), Cambridge, Cambridge University Press

Mayer C Lawrence, et al., (2003), Comparative Politics: Nations and Theories in a Changing World, 3rd Edition, Ora Publishing House, Tirana

Mill, John Stuart., (2001), Utilitarianism, Batoche Books Kitchener, Ontario

Rawls, John., (2000), Justice as Fairness, ISP\& Dita 2000, Tirana

Rousseau, Jean Jacques. (1950), The Social Contract and Discourses, G.D.H. Cole (ed), New York, Dutton

Saliu, Kurtesh., (2004), Constitutional Rights, Book I (Fourth Edition), Timegate, Pristina

Sartori, Giovanni., (1998), The theory of democracy revisited, DITURIA Publishing House

Soin, Robert., (2008), Political Europe: History. Crises, Development and Perspectives of Integration processes, Papirus, Tirana

Tinder, Glen. (1993), Political Thinking, Encyclopedia Publishing House, Tirana 